\title{
Reverse Voltage Multilevel Inverter for Photovoltaic System with Fuzzy logic based MPPT Controller
}

\author{
S.Shamshul Haq ${ }^{1}$, B.Wilson Shyam Sunder ${ }^{2}$, A.Raghu Rama Chandra ${ }^{3}$ \\ ${ }^{1}$ Department of EEE, SJCET, Kurnool, A.P, INDIA, \\ ${ }^{2}$ Department of EEE, GPCET, Kurnool, A.P,INDIA, \\ ${ }^{3}$ Department of EEE, Mahathma Gandhi Mission College of Engg, Navi Mumbai
}

\begin{abstract}
For high power equipments in Industry, application of multilevel inverter has become popular. So, multilevel inverter have been widely used for high-power high voltage distributed generation(DG) applications. In this paper Reverse voltage $(R V)$ multilevel topology is proposed, which has reduced number of switches, electromagnetic interference \& increased efficiency. This work focused on operation \& integration of a single phase $R V$ multilevel inverter with photovoltaic $(P V)$ sources. $P V$ system is made to operate with maximum power output at a point know as maximum power point(MPP).In this paper a fuzzy logic controller is used as MPPT controller. The proposed work is verified through simulation using MATLAB/SIMULINK
\end{abstract}

Keywords: Reverse voltage topology $(R V)$,photovoltaic $(P V)$, Maximum power point $(M P P), f u z z y$ logic, Distributed Generation (DG)

\section{Introduction}

Electricity generation is one of the major contributors to environmental problems. We human beings are challenged by the depletion of fossil fuel reserves. Thus development of clean energy sources is becoming increasingly important to meet these problems. Solar energy, regarded as being inexhaustible in a time frame relevant to the human race, is a truly renewable energy source. Sunlight can be directly converted into electricity by a photovoltaic effect of semiconductors. PV systems output power ranges from a few watts for applications such as calculators to mega watts power stations. These RES-based DG systems are normally stand-alone interfaced to grid through power electronics\& energy storage systems [1].

One of the most critical sections of the control system for DG unit lies within the converters control \& protection system. PV system comprises of DC-DC converter with Multilevel Inverter topology. DC/DC converter is employed to track Maximum Power Point which converts the variable DC voltage to fixed DC to exactly match the load requirement.

A conventional two- level inverter converts dc power to square wave ac power. More number of harmonics are present in square wave ac power. Further it produces higher electromagnetic interferences and low dc link voltages. Multilevel Inverter overcomes the disadvantages of conventional two level power converters. The main advantage of multilevel Inverter are higher power quality waveform, reduce voltage stress on the load \& the electromagnetic compatibility concerns[2]. One of the main drawback of multilevel power converter is higher number of switches are required which increases the cost. But as lower voltage rated switches are in this cost is not appreciably increased when compared to two level cases.

The most recently used Multilevel Inverter topologies are neutral-point- clamped(NPC) inverter, flying capacitor inverter \& cascaded converters. Some of the applications for these converters include industrial drives[3], flexible ac transmission systems(FACTS)[4]-[6] \& vehicle propulsion[7],[8].Multilevel converters are particularly suitable for renewable photovoltaic energy, that power quality \& efficiency are of great concerns[9]. In [10], [11] multiwinding transformers are used for multilevel output. These multiwinding transformers are difficult \& costly for high power applications.

This paper investigates about new multilevel inverter[12] for Photovoltaic system with fuzzy logic based MPPT system. This new multilevel inverter topology is called as reversing voltage(RV) topology. In this paper fuzzy based MPPT algorithm is implemented. MPPT methods require intelligent controllers such as fuzzy logic controllers or conventional controller such as PI controller. The MPPT using fuzzy logic controller gives good results than PI controller[13]

\section{Reverse Voltage Multilevel Inverter}

In conventional multilevel inverter the power semiconductor switches are combined to produce high frequency wave-form in negative \& positive polarities. There is no need to utilize all the power semiconductor switches for generating bipolar levels. This idea has been put into practice by the reverse voltage multilevel topology. 
Reverse Voltage topology is a hybrid multilevel topology. The output voltage is separated into two parts one part is for level generation part \& is responsible for level generation in positive polarity. It requires high frequency power semiconductors switches to produce the required levels. In this part the switches should have high - switching frequency capability.

The second part is called as polarity generation part and is responsible for polarity generation in the output voltage. The switches of this part are of low-frequency operating at line frequency. The RV topology combines high frequency \& low frequency parts to generate the multilevel voltage output. Positive levels are generated by high frequency part and then the output of this part is fed to full bridge inverter for polarity generation. This RV topology eliminates many of the semiconductor switches to generate required output voltage levels in positive \& negative polarities.

The schematic diagram of RV topology in seven levels is as shown in fig.1.It requires ten switches \& three isolated source to have seven level of output. The principle idea of this multilevel inverter is that the left circuit in fig.1.generates the required output level without polarity. The right circuit(full bridge) decides the polarity of the output voltage. The right circuit transfers the required output level to the output with the same direction or opposite direction according to the required output. It reverses the voltage phase when the voltage phase requires to be changed for negative polarity.

The main advantages of proposed topology are i)It can be easily extended to higher voltage levels by adding the middle stage as shown in Fig.2. ii) It can be easily applied for three phase applications with same operating principle.iii)It uses isolated dc supplies \& therefore voltage balancing problem does not come exist.iv)This topology uses less components when compared to conventional inverter. v)It just requires only half of conventional carriers for SPWM controller.vi)It does not need fast switches for polarity generation part.

In this paper reverse voltage multilevel topology is design for seven level output, dc source are replaced by PV systems. For generation of seven level output this topology requires three source. This topology is a symmetrical topology as all the values of all voltage sources are equal. It is applicable for asymmetrical topology also. A multilevel modulation phase disposition (PD) SPWM is used to drive the inverter \& it can be extended to higher voltage levels.

\section{Table}

Comparison of Components Required for Inverter Topology

\begin{tabular}{|l|l|l|l|c|}
\hline Type of Inverter & Main Switches & Main diodes & Clamping Diodes & Flying Capacitor \\
\hline NCP & $6(\mathrm{~N}-1)$ & $6(\mathrm{~N}-1)$ & $3(\mathrm{~N}-1)(\mathrm{N}-2)$ & 0 \\
\hline Flying Capacitor & $6(\mathrm{~N}-1)$ & $6(\mathrm{~N}-1)$ & 0 & $3 / 2(\mathrm{~N}-1)(\mathrm{N}-2)$ \\
\hline Cascaded & $6(\mathrm{~N}-1)$ & $6(\mathrm{~N}-1)$ & 0 & 0 \\
\hline Reverse Voltage & $3((\mathrm{~N}-1)+4)$ & $3((\mathrm{~N}-1)+4)$ & 0 & 0 \\
\hline
\end{tabular}

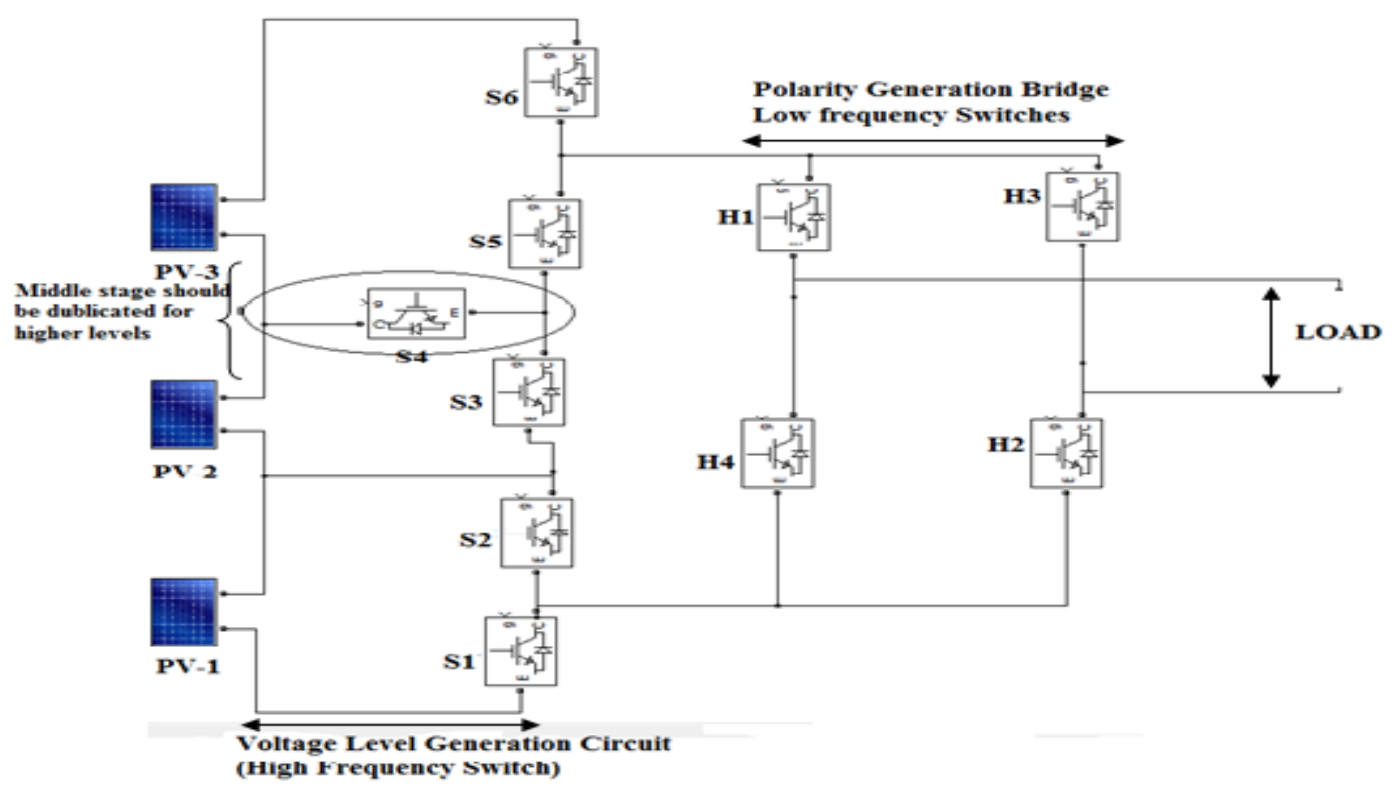

Fig.1.Schematic diagram of proposed single phase seven level inverter 


\section{Photovoltaic Cell Model}

In simulation mathematical equations describing the system characteristics are formulated \&translated into computer codes. Single diode circuit model is most commonly used to analyze the energy generation in a photovoltaic cell that represent the electrical behavior of the pn-junction. An ideal module consists of a single diode connected in parallel with a light generated current source as shown in Fig.2.

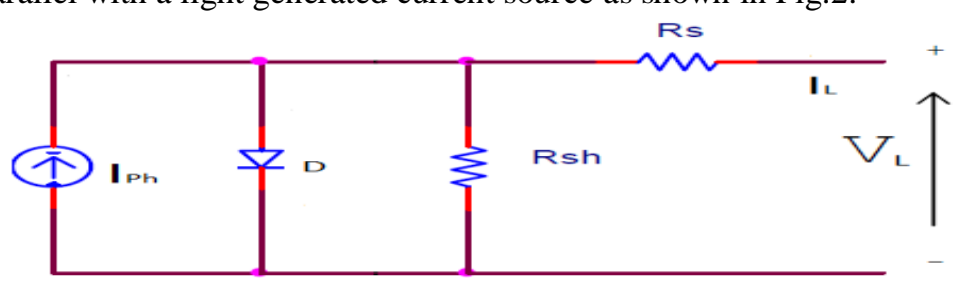

Fig.2.Equivalent Circuit of PV cell

Where $I_{p h}$ represents cell photo current $R_{s} \& R_{s h}$ indicate the intrinsic shunt \& series resistances of the cell. PV cells are inter-connected to form larger unit called as PV modules \& these modules are inter connected in parallel/series to form PV arrays. Photovoltaic penal is modeled using the mathematical equations $(1)-(4)$ [14] - [15]

The equation for module photo - current is given as

$\mathrm{Iph}=[\mathrm{Iscr}+\mathrm{Ki}(\mathrm{T}-298)] * \alpha / 1000$

Reverse saturation current (Irs ) is given as

$\operatorname{Irs}=\operatorname{Iscr} /[\exp (q \operatorname{Voc} /$ NsKAT $)-1]$

As the temperature varies module saturation current (Io) varies ,It is given

$\mathrm{Io}=\mathrm{Irs}[\mathrm{T} / \mathrm{Tr}]^{3} \exp \left[\mathrm{q}^{*} \mathrm{Ego} / \mathrm{BK}\{1 / \mathrm{Tr}-1 / \mathrm{T}\}\right]$

Output current of PV module is given as

$I_{L}=N p * I p h-N p * \operatorname{Io}[\exp \{q *(V p v+I p v R s) / N s A K T\}-1]$

The proposed model consists of No. cells connected in parallel( $\mathrm{Np})=1$, No. of cells connected in $\operatorname{series}(\mathrm{Ns})=36$

Where $\mathrm{V}_{\mathrm{L}}, \mathrm{I}_{\mathrm{L}}, \mathrm{Tr}$, $\mathrm{T}$, Iph, Io,Iscr are output voltage, output current of pv module, reference temperature ,operating temperature, light generated current, module saturation current, module short circuit current.

TABLE 2

Electrical characteristics data of solar36 KW PV module

\begin{tabular}{|l|c|}
\hline Rated Power & $37.8 \mathrm{~W}$ \\
\hline Current at Maximum Point (Impp) & $2.25 \mathrm{~A}$ \\
\hline Voltage at Maximum Point (Vmpp) & $16.56 \mathrm{~V}$ \\
\hline Short Circuit Current ( Vsc) & 2.55 \\
\hline Open Circuit Voltage ( Voc) & 21.24 \\
\hline No.of cells in parallel (Np) & 1 \\
\hline No. of cells in series (Ns) & 36 \\
\hline
\end{tabular}

The above electrical specifications are under conditions of irradiance of $1 \mathrm{KW} / \mathrm{m}^{2}$, spectrum of 1.5 air mass \& cell temperature of $25^{\circ} \mathrm{C}$. The P-V \& I-V characteristics of PV array for different irradiation are obtained as show below in Fig. $3 \&$ Fig. 4 


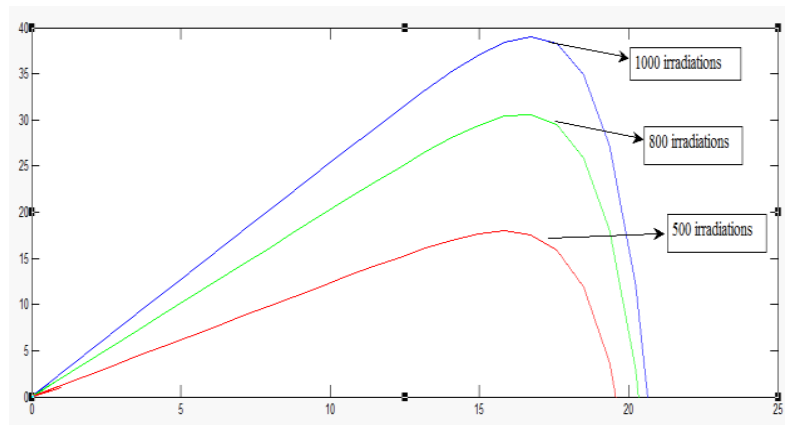

Fig. 3.Characteristics Power Vs Voltage

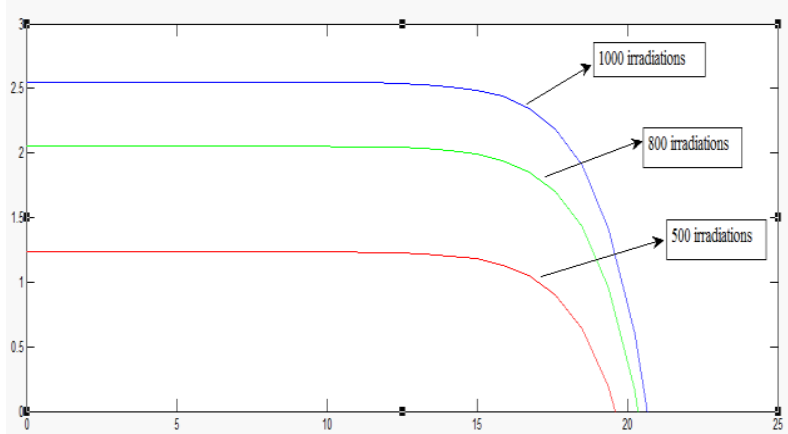

Fig.4.Characteristics Current Vs Voltage

The simulink model of PV module is modeled using equations (1)- (4) .

\section{Dc - Dc Boost Converter}

It is a power electronic device $\&$ it has a capability of providing an voltage which is higher than the input voltage [16]. The circuit diagram of a boost converter is shown in Fig.5

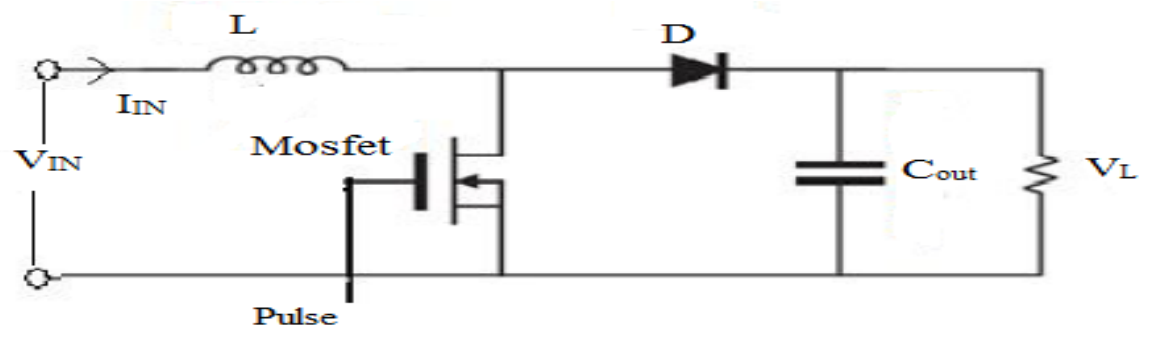

Fig.5.Boost Converter

In boost converter value of $\mathrm{L}$ is calculated such that the peak current of inductor at maximum input power does not exceed the power switch current rating.

$$
\mathrm{L} \geq \operatorname{Vm}(1-\mathrm{D}) \mathrm{D} / \mathrm{fs}|\Delta \mathrm{I}|
$$

Where fs is switching frequency, $\mathrm{D}$ is the duty cycle at maximum input power of the converter, $\Delta \mathrm{I}$ is the ripple of inductor current, $\mathrm{Vm}$ and Im the maximum output voltage and current at maximum output power. Capacitor value at the input is calculated as

$$
\mathrm{Ci} \geq \mathrm{ImD}^{2} /[0.02(1-\mathrm{D}) \text { Vinfs }]
$$

Where Vin is the input voltage of photovoltaic input voltage at maximum power point. Output capacitor value is calculated as

Where $r$ is the output ripple factor.

$$
\mathrm{Co} \geq \mathrm{DI}_{\text {out }} / \mathrm{rfsV}_{\text {out }}
$$

\section{Fuzzy Logic Mppt Controller}

Lotfi Zadeh, the father of fuzzy logic, claimed that many sets surrounding us are defined by a non distinct by a non - distinct boundary. He extern ad two valued logic, defined by pair of binary $\{0,1\}$, to the whole continuous internal [0,1], there by introducing a gradual transition of false to truth [17]. It provides a general method of expressing linguistic rules based on fuzzy sets \& fuzzy algorithms. The main advantages of fuzzy logic controller are it does not requires any mathematical model of the system. Complex systems deal with complex systems can be controlled without the knowledge of exact mathematical model of the system.

The fuzzy logic controller consists of three blocks -
1. Fuzzification
2.Inference
3.Defuzzification.

In the proposed fuzzy logic based technique the error(E) \& changing of error $(\mathrm{CE})$ are the inputs. The error value is calculated as in equation (9)\& (10),

$$
\begin{aligned}
& \mathrm{E}(\mathrm{K})=\frac{\mathrm{dp}}{\mathrm{dv}}=\frac{\mathrm{Pph}(\mathrm{K})-\mathrm{Pph}(\mathrm{K}-1)}{\mathrm{Vph}(\mathrm{K})-\mathrm{Vph}(\mathrm{K}-1)} \\
& C E(K)=E(K)-E(K-1)
\end{aligned}
$$

Where $\operatorname{Pph}(\mathrm{K})$ is the power of the photovoltaic system. In this proposed work the inputs of the fuzzy logic are expressed in five linguistic variables, As shown in Fig.6a \& Fig.6b 


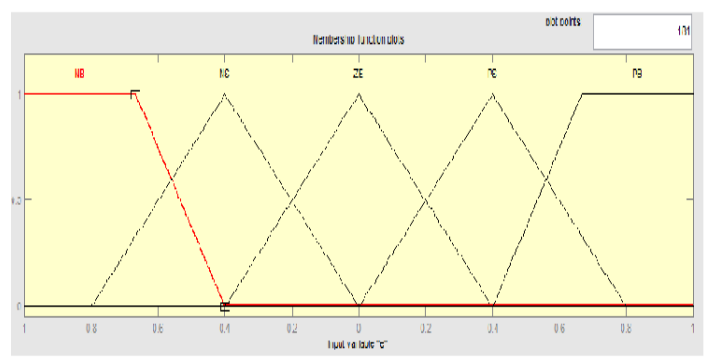

Fig(6a) Input Variable "error"

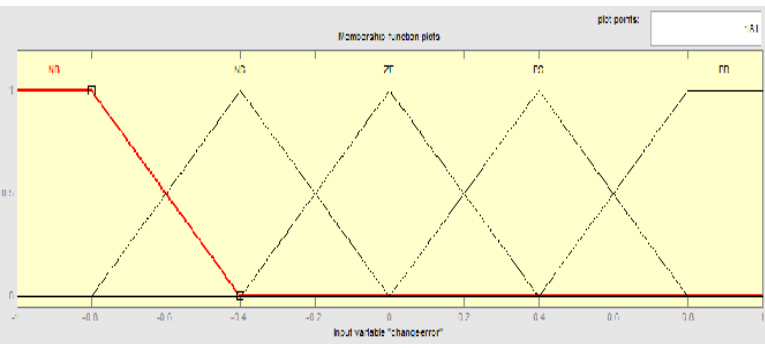

Fig(6b) Input Variable "Change in error"

The control surface which relates the input \& output variables of the system are governed with a set of rules. A rule would be "If $x$ is A Then $y$ is B", the rule table is as show in Fig.7a.\&Fig.7b shows the surface rlue viewer.

\begin{tabular}{|c|c|c|c|c|c|}
\hline EE & NB & NS & ZE & PS & PB \\
\hline NB & ZE & ZE & PB & PB & PB \\
\hline NS & ZE & ZE & PS & PS & PS \\
\hline ZE & PS & ZE & ZE & ZE & NS \\
\hline PS & NS & NS & NS & ZE & ZE \\
\hline PB & NS & NB & NB & ZE & ZE \\
\hline
\end{tabular}

Fig.7a. Fuzzy Logic Rules

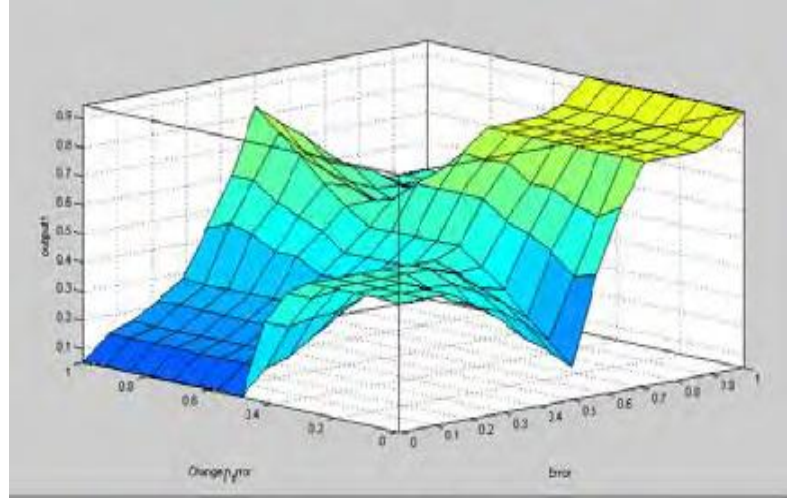

Table Fig.7b. Surface Rule Viewer

The control scheme of Fuzzy controller based MPPT for PV module is represented as shown in Fig .8

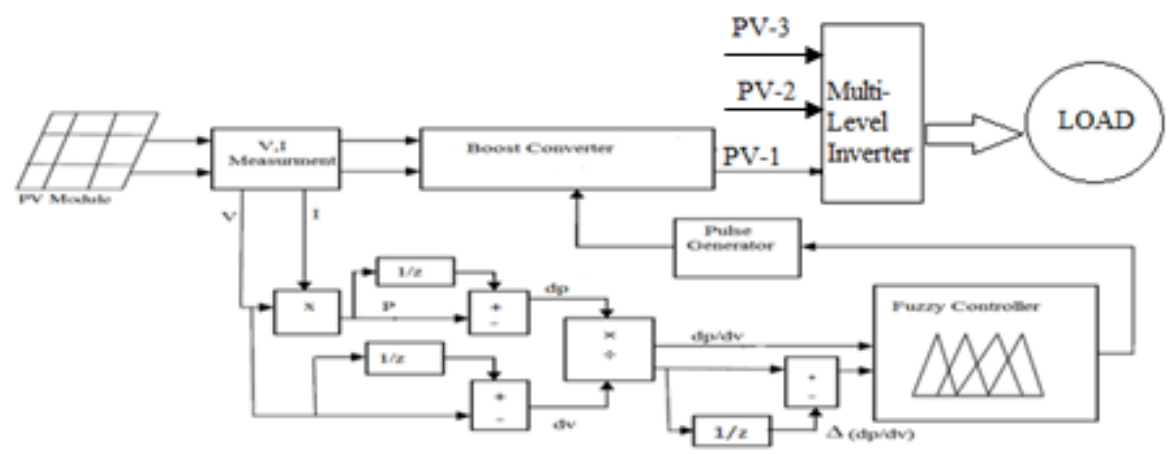

Fig.8.Block diagram of Fuzzy controller based MPPT for PV module

\section{Simulation Results}

The carrier signal $\left(\mathrm{V}_{\mathrm{c}}\right)$ \& reference signals $\left(\mathrm{V}_{\mathrm{r}}\right)$ are as shown in Fig .9. The carrier signal is compared with the reference signal. If the reference signal is greater than or equal to the carrier signal than a triggering pulse is generated. A pattern is adopted to have the required voltage levels.

The proposed system is designed \& simulated for seven level output using MATLAB/SIMULINK as shown in Fig.10. The PV module is coupled with a boost converter with fuzzy MPPT. Boost converter with fuzzy MPPT make the PV module to operate at maximum power point. The output voltage of PV module at MPPT is $17 \mathrm{v}$. The boost converter boost the voltage to 33v.Output voltage of boost converter is in the input voltage of each source of multilevel inverter. A RL load is consider here with $\mathrm{R}=100 \mathrm{ohms} \mathrm{\&} \mathrm{L}=1 \mathrm{e}^{-3} \mathrm{H}$. The output voltage and current waveform of multilevel inverter is as shown in Fig.11\& Fig. 12. 


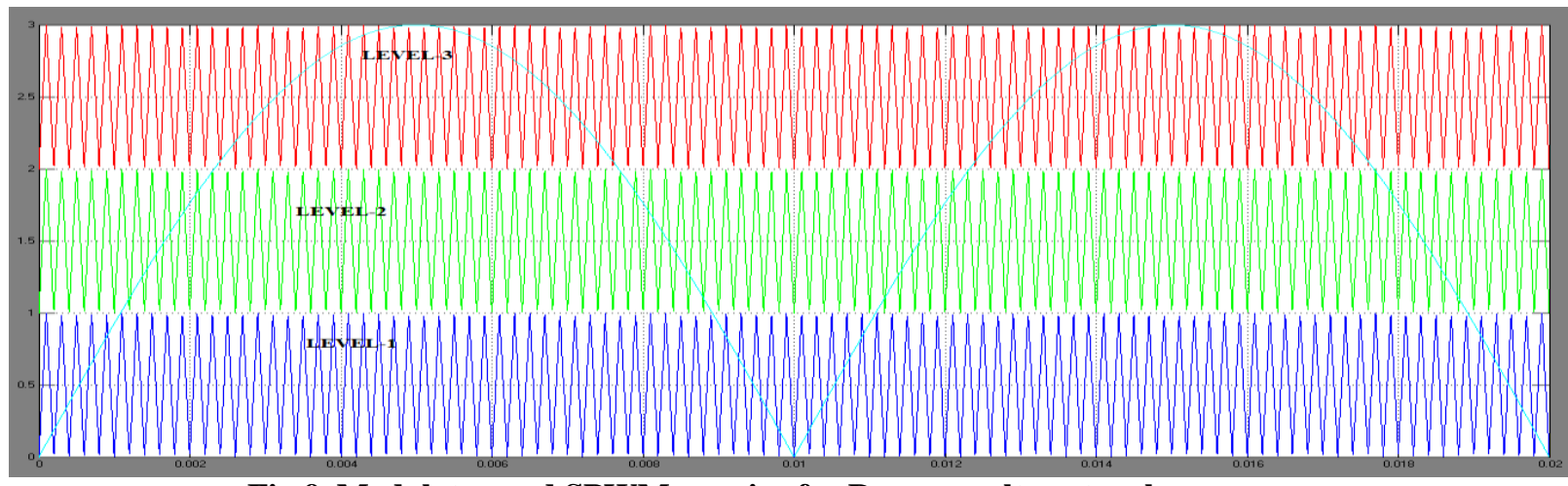

Fig.9. Modulator and SPWM carrier for Reverse voltage topology

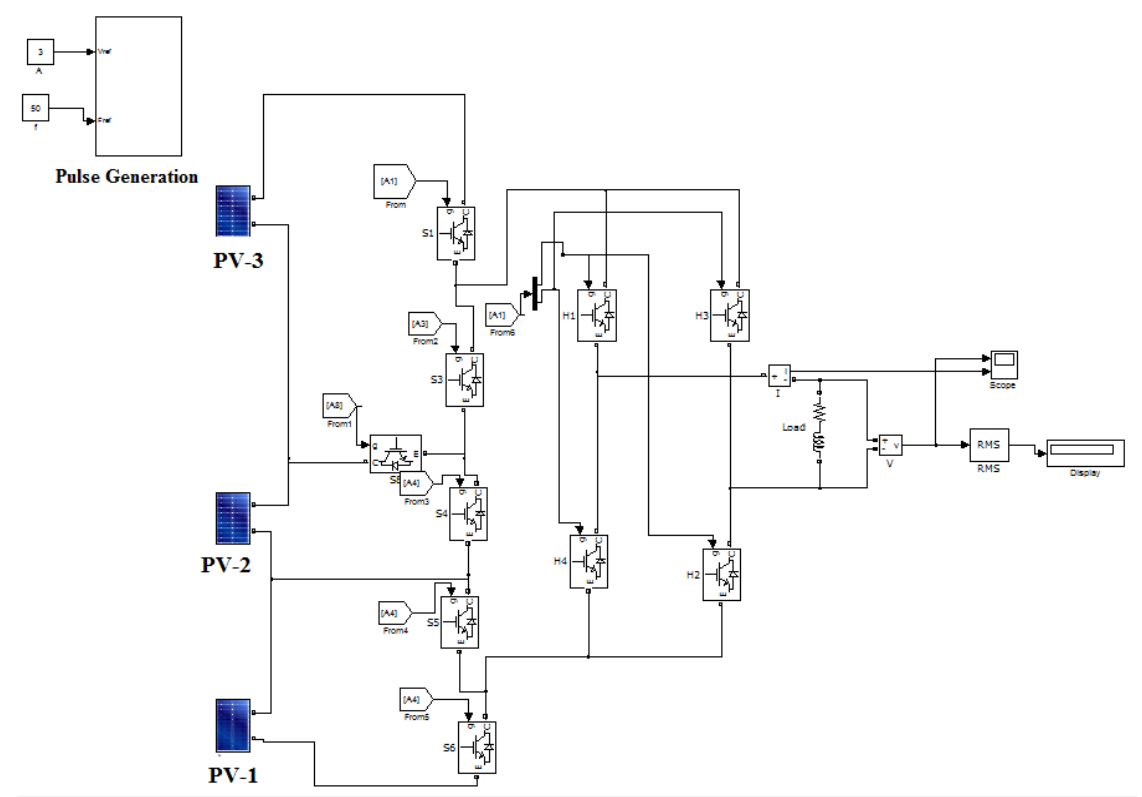

Fig.10.Simulink model of RV multilevel inverter with PV sources with fuzzy mppt controller

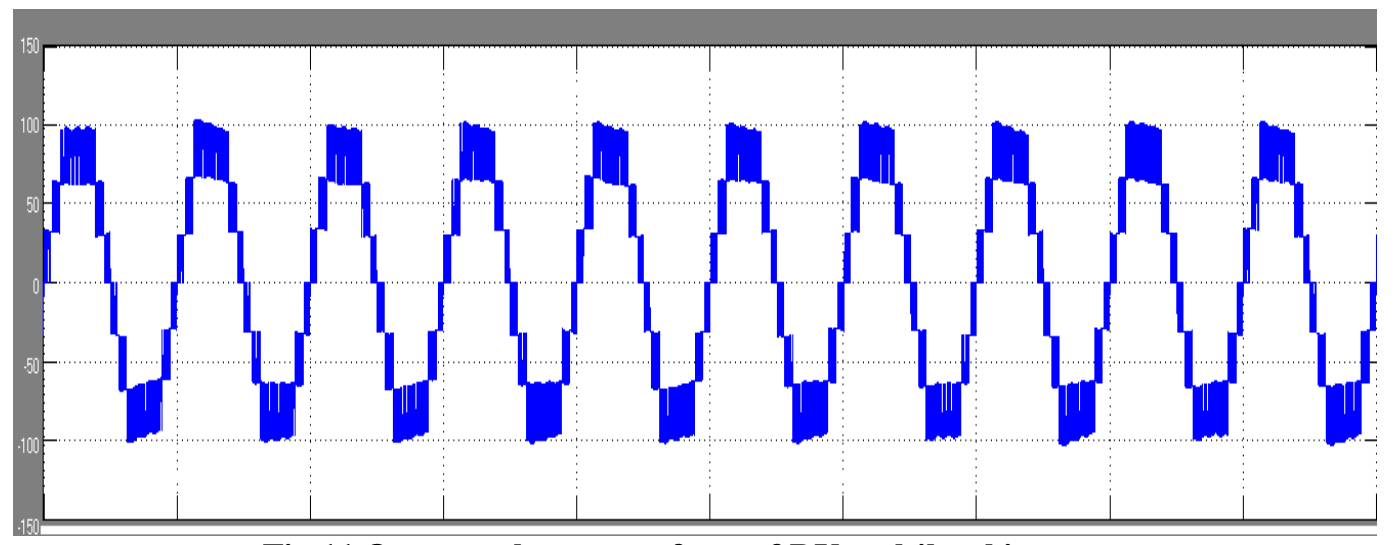

Fig.11.Output voltage waveform of $\mathrm{RV}$ multilevel inverter 


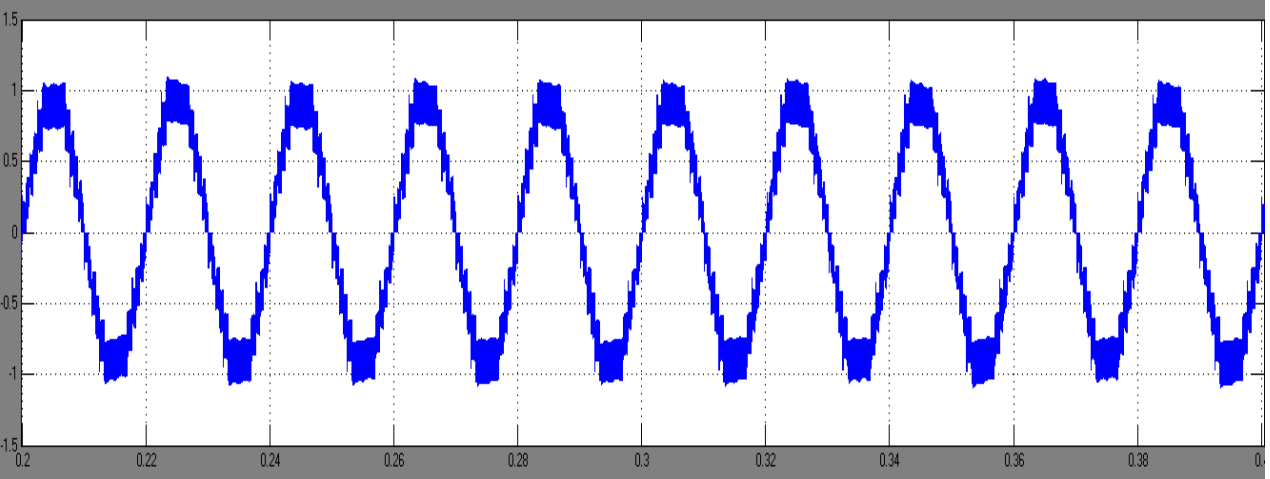

Fig.12.Output current waveform of RV multilevel inverter

\section{Conclusion}

In this paper reverse voltage multilevel topology has been proposed for photovoltaic system. RV topology has superior features over conventional topologies in terms of required power switches, dc supplies, control requirements, cost \& reliability. The result shows that this topology is a good candidate for converters used in power applications such as HVDC, UPS, FACTS, etc. As the switching operation is separated into high \& low frequency part, It will increase the efficiency as well as the cost. Further this work can be extended for higher levels \& other power system applications.

\section{Acknowledgement}

We thank all who all motivated and guided us directly \& indirectly in every step.

\section{Reference}

[1] J M. Carrasco, L. G. Franquelo, J. T. Bialasiewicz, E. Galvan, R. C. P. Guisado, Ma. A. M. Prats, J. I. Leon, and N. MorenoAlfonso, "Power-electronic systems for the grid integration of renewable energy sources: a survey," IEEE Trans. Ind. Electron., vol. 53, no. 4, pp. 1002-1016, Aug. 2006.

[2] K. Jang-Hwan, S.-K.Sul, and P. N. Enjeti, "A carrier-based PWM method with optimal switching sequence for a multilevel four-leg voltage source inverter,” IEEE Trans. Ind. Appl., vol. 44, no. 4, pp. 1239-1248, Jul./Aug. 2008.

[3] R. H. Osman, “A medium-voltage drive utilizing series-cell multilevel topology for outstanding power quality," in Conf. Rec. 34th IEEE IAS Annu. Meeting, 1999, vol. 4, pp. 2662-2669.

[4] E. Najafi and A. H. M. Yatim, "A novel current mode controller for a static compensator utilizing Goertzel algorithm to mitigate voltage sags," Energy Convers.Manage., vol. 52, no. 4, pp. 1999-2008, Apr. 2011

[5] N. Seki and H. Uchino, "Converter configurations and switching frequency for a GTO reactive power compensator," IEEE Trans. Ind. Appl., vol. 33, no. 4, pp. 1011-1018, Jul./Aug. 1997.

[6] G. Shahgholiyan, E. Haghjou, and S. Abazari, "Improving the mitigationof voltage flicker by usage of fuzzy control in a distribution static synchronouscompensator (DSTATCOM)," Majlesi J. Elect. Eng., vol. 3, no. 2,pp. 25-35, Jun. 2009.

[7] K. Nakata, K. Nakamura, S. Ito, and K. Jinbo, “A three-level tractioninverter with IGBTs for EMU," in Conf. Rec. IEEE IAS Annu. Meeting,1994, vol. 1, pp. 667-672.

[8] A. Jidin, N. R. N. Idris, A. H. M. Yatim, T. Sutikno, and M. E. Elbuluk, “An optimized switching strategy for quick dynamic torque control inDTC-hysteresis-based induction machines,” IEEE Trans. Ind. Electron.,vol. 58, no. 8, pp. 3391-3400, Aug. 2011.

[9] K. Y. Lau, M. F. M. Yousof, S. N. M. Arshad, M. Anwari, andA. H. M. Yatim, "Performance analysis of hybrid photovoltaic/dieselenergy system under Malaysian conditions," J. Energy, vol. 35, no. 8,pp. 3245-3255, Aug. 2010.

[10] R. Teodorescu, F. Blaabjerg, J. K. Pedersen, E. Cengelci, andP. N. Enjeti, "Multilevel inverter by cascading industrial VSI," IEEE Trans. Ind. Electron., vol. 49, no. 4, pp. 832-838, Aug. 2002.

[11] D. A. B. Zambra, C. Rech, and J. R. Pinheiro, "A comparative analysisbetween the symmetric and the hybrid asymmetric nine-level series connectedH-bridge cells inverter," in Proc. Eur. Conf. Power Electron. Appl.,2007, pp. 1-10.

[12] EhsanNajafi, , Abdul Halim Mohamed Yatim," Design and Implementation of a New MultilevelInverter Topology", IEEE Trans industrial electronics, vol. 59, no. 11, november 2012

[13] S. ShamshulHaq, B. Wilson Shyamsunder, G. Mohammad Zameer "Design and simulation of mppt algorithm of photovoltaic system using intelligent controller", IJASTR Issue 3 volume 6, Nov.-Dec. 2013

[14] S.Chowdhury, S.P.Chowdhury, G.A.Taylor, and Y.H.Song, "Mathematical Modeling and Performance Evaluation of a Stand-Alone Polycrystalline PV Plant with MPPT Facility," IEEE Power and Energy Society General Meeting - Conversion and Delivery of Electrical Energy in the 21st Century, July 20-24, 2008, Pittsburg, USA.

[15] S. Nema, R.K.Nema, and G.Agnihotri, "Matlab / simulink based study of photovoltaic cells / modules / array and their experimental verification," International Journal of Energy and Environment, pp.487- 500, Volume 1, Issue 3, 2010.

[16] J.H.Su, J.J.Chen, and D.S.Wu, "Learning feedback controller design of switching converters via MATLAB/SIMULINK," IEEE Trans. Educ., vol. 45, no. 4, pp. 307-315, Nov. 2002.

[17] J. Jantzen, "Tutorial on Fuzzy Logic", Technical University of Denmark: Department of Automation, Technical report number 98-E 868, 19 Aug 1998, URL: http://www.iau.dtu.dk 